\title{
Tingkat Pengetahuan Ibu Menyusui Tentang KB Alamiah Metode Amenore Laktasi di Klinik Bidan Kristina Perumnas Kalsim Kota Sidikalang Tahuan 2021
}

\begin{abstract}
Penulis:
Risda Mariana Manik ${ }^{1}$ Merlina Sinabariba ${ }^{2}$

Pul Siola Natalia

Simamora ${ }^{3}$

Afiliasi:

Program Studi Diploma

3 Kebidanan, Sekolah

Tinggi Ilmu Kesehatan

Santa Elisabeth, Medan, Indonesia ${ }^{1,2,3}$

Korespondensi: pulsioola@gmail.com

Histori Naskah: Diajukan: 2021-12-15

Disetujui: 2021-12-15

Publikasi: 2022-01-10

Abstrak:

Metode Amenore Laktasi adalah kontrasepsi yang mengandalkan pemberian Air Susu Ibu (ASI) secara eksklusif artinya hanya diberikan ASI saja tanpa pemeberian makanan tambahan atau minuman apapun. (Srihandayani, 2018). Penggunaan kontrasepsi alamiah Metode Amenorea Laktasi (MAL) secara tidak langsung memberikan dampak pengurangan resiko kematian ibu akibat perdarahan pasca persalinan (Melyani,2017). Metode Amenorea Laktasi (MAL) adalah kontrasepsi yang mengandalkan pemberian Air Susu Ibu (ASI) secara eksklusif. Keuntungan MAL diantaranya efektivitas tinggi $98 \%$ dan tanpa biaya. Keuntungan untuk bayi yaitu bayi mendapatkan antibodi melalui ASI dan sebagai sumber asupan gizi untuk tumbuh kembang bayi Berdasarkan studi pendahuluan yang dilakukan oleh peneliti di Puskesmas Bangetayu, diperoleh hasil bahwa sebanyak 10 dari 12 ibu hamil trimester III belum pernah mendapatkan penyuluhan atau informasi tentang metode amenorea laktasi (MAL). Sampel yang digunakan dalam penelitian ini di tentukan dengan teknik metode Accidental Sampling dengan jumlah sampel 20 orang. Dari hasil penelitian ini berdasarkan pengetahuan ibu menyusui sebahagian besar berpengatahuan cukup, pendidikan SMA sebanyak 11 orang (55\%), berpendidikan SMA sebanyak 10 orang (50\%) dan mayoritas pekerjaan sebagai Petani sebanyak 11 orang $(55 \%)$ berpengetahuan baik. Saran kepada tenaga kesehatan agar dapat menerapkan metode Alamiah Amenore Laktasi kepada ibu yang menyusui dan kepada peneliti selanjutnya supaya menjadi masukan untuk menambah wawasan, informasi dan panduan dalam penelitian lebih lanjut tentang KB Alamiah Metode Amenore Laktasi (MAL).
\end{abstract}

Kata kunci: Ibu Menyusui, KB Alamiah, Amenore Laktasi, Klinik Bidan

\section{Pendahuluan}

Metode Amenore Laktasi adalah kontrasepsi yang mengandalkan pemberian Air Susu Ibu (ASI) secara eksklusif artinya hanya diberikan ASI saja tanpa pemeberian makanan tambahan atau minuman apapun. (Srihandayani, 2018). Penggunaan kontrasepsi alamiah Metode Amenorea Laktasi (MAL) secara tidak langsung memberikan dampak pengurangan resiko kematian ibu akibat perdarahan pasca persalinan (Melyani,2017). Metode Amenorea Laktasi (MAL) adalah kontrasepsi yang mengandalkan pemberian Air Susu Ibu (ASI) secara eksklusif. Keuntungan MAL diantaranya efektivitas tinggi $98 \%$ dan tanpa biaya. Keuntungan untuk bayi yaitu bayi mendapatkan antibodi melalui ASI dan sebagai sumber asupan gizi untuk tumbuh kembang bayi Berdasarkan studi pendahuluan yang dilakukan oleh peneliti di Puskesmas Bangetayu, diperoleh hasil bahwa sebanyak 10 dari 12 ibu hamil trimester III belum pernah mendapatkan penyuluhan atau informasi tentang metode amenorea laktasi (MAL).

Berdasarkan data dari WHO (World Healt organization) penggunaan kontrasepsi telah meningkat di banyak bagian dunia. Terutama di Asia dan Amerika latin. Tetapi tetap rendah di Afrika Sub-Sahara. Di Afria dari 61,8\%. Dan di Afrika latin dan Karibia tetap stabil sebanyak 66,7\% ( World Healt Organization,2018). Data World Healt Organization $i$ (WHO) menunjukkan bahwa pengguna alat 
kontrasepsi Implan di seluruh Dunia masih di bawah alat kontrasepsi suntik, pil dan IUD,terutama di negara negara berkembang. Persentase penggunaan alat kontrasepsi KB suntik yaitu 35,5\%, KB pil yaitu 30,5\%, KB IUD yaitu 15,2\% sedangkan KB Implan dibawah 10\% Yaitu 7,3\% dan alat kontrasepsi lainnya sebesar $11,7 \%$.

Profil Kesehatan Indonesia, (2018) cakupan Pasangan Usia Subur (PUS) berdasarkan kepesertaan ber-KB 2018 adalah KB aktif diantara PUS tahun 2018 sebesar 63,27\% sedangkan yang tidak pernah ber-KB sebesar 18,82\%. Pemakaian alat kontrasepsi di Indonesia berdasarkan cakupan peserta KB aktif menurut kontrasepsi modren 2018 yaitu suntik 63,71\%, pil 17,24\%, IUD 7,35\%, implan 7,20\%, MOW 2,76\%, kondom 1,24\%, dan MOP 0,50\% (Profil Kesehatan Indonesia, 2018).

Jumlah Penduduk Sumatera Utara pada 2018 mencapai 14.420.000 jiwa. Berdasarkan data Badan Pusat Statistik (BPS), jumlah tersebut terdiri atas 7.190.000 jiwa laki-laki dan 7.2 20.000 jiwa perempuan. Berdasarkan data BKKBN Sumatera Utara, jumlah peserta KB baru sampai tahun 2017 adalah sebanyak 371.398 jiwa dari PUS yang ada atau sebesar 15,44\%, meningkat dibandingkan dengan tahun 2016 (sebanyak 350. 481 jiwa atau 14,83\%). Sementara presentase jenis alat kontrasepsi yang digunakan peserta KB aktif Provinsi Sumatera Utara tahun 2017 adalah suntik 13,05\%, pil 11,22\%, implan 4,97\%, kondom 3,97\%, IUD 1,52\%, MOW 1,04\%, MOP 0,11\% (Profil Kesehatan Sumatera Utara, 2017).

Dari data tersebut KB Implant dan IUD merupakan MKJP yang dapat digunakan oleh wanita usia subur yang masih mempunyai program ingin memiliki anak. Kesadaran masyarakat terhadap program keluarga berencana (KB), yakni dengan menundah usia pernikahan, mengatur jarak kelahiran anak, serta membatasi jumlah anak membuat angka kelahiran bayi cenderung menurun. Sementara angka kematian jutru terlihat meningkat seiring makin banyak penduduk usia yang tutup usia. (BKKBN, 2017).

\section{Metode Penelitian}

Rancangan penelitian yang dilakukan ini bersifat deskriptif yang bertujuan untuk mengetahui masalah dalam penelitian ini adalah memeberikan Tingkat Pengetahuan Ibu Menyusui Tentang KB Alamiah Metode Amenore Laktasi Di Klinik Bidan Kristina Perumnas Kalsim Tahun 2021.

Populasi penelitian yaitu subjek seperti manusia maupun klien yang mempunyai kriteria tertentu sesuai dengan yang diharapkan oleh peneliti (nursalam, 2017). Dalam hal ini populasi dalam penelitian ini adalah semua ibu menyusui berkisar 20 orang secara eksklusif dan mempunyai bayi usia 0-6 bulan di Klinik Bidan Kristina Perumnas Kalsim Kota Sidikalang

Sampel saya semua ibu menyusui yang berkunjung di Klinik Bidan Kristina Hutahaen Perumnas Kalsim Tahun 2021. Sampel dalam penelitian ini di tentukan dengan teknik metode Acidental Sampling dengan jumlah sampel 20 orang dimana pengambilan samplin ini di lakukan dengan pemngambilan kasus atau responden yang kebetulan datang ke klinik sesuai dengan konteks penelitian.

\section{Hasil}

Tabel 1 Distribusi Frekuensi Karakteristik Responden Tentang Tingkat Pendidikan, Pekerjaan Ibu Menyusui Tentang KB Alamiah Amenore Laktasi Di Klinik Bisan Kristina Perumnas Kalsil Tahun 2021

Karakteristik (f) (\%)

Pendidikan 


\section{Health Caring: Jurnal Illmiah Kesehatan}

Volume: 1 | Nomor 1 | Januari 2022 | E-ISSN: xxxx-Xxxx |

DOI: doi.org/healthcaring.v1n1.1248

\begin{tabular}{lll}
\hline \hline SD & 1 & 5 \\
SMP & 3 & 15 \\
SMA & 13 & 65 \\
PT & 3 & 15 \\
\hline Jumlah & $\mathbf{2 0}$ & $\mathbf{1 0 0}$ \\
\hline Pekerjaan & & \\
Petani & 17 & 85 \\
Swasta & 2 & 10 \\
Wiraswasta & 1 & 5 \\
\hline Jumlah & $\mathbf{2 0}$ & $\mathbf{1 0 0}$ \\
\hline
\end{tabular}

Menunjukkan bahwa pendidikan respoden sebagian besar SMA sebanyak 13 (65\%), dan sebagian kecil pendidikan SD 1 orang (5\%). Pekerjaan responden sebagian besar sebagai Petani 17 orang 85,0\%), Wiraswasta sebagian kecil 1 orang (5\%).

Tabel 2 Distribusi Pengetahuan Ibu Menyusui Tentang KB Alamiah Metode Amenore Laktasi di Klinik Bidan Kristina Taun 2021 Distribusi Pengetahuan Responden Berdasarkan Pendidikan

\begin{tabular}{llll} 
No & Pengetahuan & $\mathbf{f}$ & $(\boldsymbol{\%})$ \\
\hline 1 & Baik & 13 & $65 \%$ \\
2 & Cukup & 1 & $5 \%$ \\
3 & Kurang & 6 & $30 \%$
\end{tabular}

\begin{tabular}{lll}
\hline Jumlah & 20 & 100
\end{tabular}

Tabel 5.2 Menunjukkan bahwa pengetahuan Ibu Menysui Tentang KB Alamiah Metode Amenore Laktasi Di Klinik Bidan Kristina Perumnas Kalsim dengan jumlah 20 responden 13 orang berpengetahuan baik $(65,0 \%)$ berpengetahuan cukup sebanyak 1 orang $(5,0 \%)$ berpengetahuan kurang 6 orang $(30 \%)$.

Tabel 3 Distribusi Pengetahuan Responden Tentang KB Alamiah Metode Amenore Laktasi Berdasarkan Pendidikan Di Klinik Bidan Kristina Hutahaen Perumnas Kalsim Tahun 2021.

\section{Pendidikan}


Volume: 1 | Nomor 1 | Januari 2022 | E-ISSN: xxxx-Xxxx |

DOI: doi.org/healthcaring.v1n1.1248

\begin{tabular}{llllllllll}
\hline \hline \multirow{2}{*}{ Karekteristik } & Baik & \multicolumn{1}{c}{ Cukup Kurang } & \multicolumn{1}{c}{ Jumlah } & & & \\
& f & \% & $\mathbf{f} \%$ & $\mathbf{f}$ & $\mathbf{\%}$ & $\mathbf{f}$ & $\mathbf{\%}$ & \\
\hline Pendidikan & & & & & & & & & \\
SD & 0 & 0,0 & 0 & 0,0 & 1 & 5,0 & 1 & 5,0 \\
SMP & 1 & 5,0 & 0 & 0,0 & 2 & 10,0 & 3 & 15,0 \\
SMA & 10 & 50,0 & 1 & 5,0 & 2 & 10,0 & 13 & 65,0 \\
PT & 2 & 10,0 & 0 & 0,0 & 1 & 5,0 & & 3 & 15,0 \\
& & & & & & & & & \\
\hline Jumlah3 & $\mathbf{1 5 , 0}$ & $\mathbf{1 1}$ & $\mathbf{5 5 , 0}$ & $\mathbf{6}$ & $\mathbf{3 0 , 0}$ & & $\mathbf{2 0}$ & $\mathbf{1 0 0 , 0}$ & \\
\hline
\end{tabular}

Berdasarkan tabel 5.4 Pendidikan SD diatas sebagian besar berpengetahuan kurang sebanyak 1 orang. Pendidikan SMP berpengetahuan baik sebanyak 1 orang $(5,0 \%)$ berpengetahuan kurang 2 orang $(10 \%)$. Pendidikan SMA berpengetahuan baik 10 orang (50\%) cukup 1 orang $(5,0 \%)$ kurang 2 orang $(10,0 \%)$. Perguruan Tinggi berpengetahuan baik sebanyak 2 orang (10\%) berpengetahuan cukup 1 orang (5,0\%) berpengetahuan kurang orang.

Tabel 4 Distribusi Pengetahuan Responden Tentang KB Alamiah Metode Amenore Laktasi Berdasarkan Pekerjaan Di Klinik Bidan Kristina Hutahaen Perumnas Kalsim Tahun 2021.

\section{Pengetahuan}

\begin{tabular}{|c|c|c|c|c|c|c|c|c|c|}
\hline \multirow{2}{*}{\multicolumn{2}{|c|}{$\begin{array}{c}\text { Karekteristik Baik } \\
\text { f }\end{array}$}} & \multicolumn{2}{|c|}{ Cukup } & \multicolumn{2}{|c|}{ Kurang } & \multicolumn{2}{|c|}{ Jumlah } & \multirow[b]{2}{*}{$\mathbf{f}$} & \multirow[b]{2}{*}{$\%$} \\
\hline & & $\%$ & f & $\%$ & $\mathbf{f}$ & $\%$ & & & \\
\hline \multicolumn{10}{|l|}{ Pekerjaan } \\
\hline Petani & 11 & 55,0 & 1 & 5,0 & 5 & 25,0 & & 17 & 85,0 \\
\hline Wiraswasta & 2 & 10,0 & 0 & 0,0 & 0 & 0,0 & & 2 & 10,0 \\
\hline Swasta & 0 & 0,0 & 0 & 0,0 & 1 & 0,0 & & 2 & 10,0 \\
\hline Jumlah3 & 15,0 & 11 & $\mathbf{5 5 , 0}$ & 6 & $\mathbf{3 0 , 0}$ & & 20 & 100,0 & \\
\hline
\end{tabular}

Berdasarkan tabel diatas dari pekerjaaan Petani sebagian besar berpengetahuan baik 11 orang $(55,0 \%)$ berpengetahuan cukup 1 orang berpengetahuan kurang 6 orang. Berdasarkan pekerjaan wiraswasta berpengetahuan baik ada sebanyak 2 orang (5\%), Berdasarkan pekerjaan Swasta berpengetahuan kurang ada sebanyak 1 orang $(5 \%)$. 


\section{Pembahasan}

Berdasarkan hasil penelitian tabel diketahui dari 20 orang responden bahwa tingkat pengetahuan ibu menyusui tentang KB Alamiah Metode Amenore Laktasi Di Klinik Bidan kristina Perumnas Kalsim dengan jumlah 20 responden 13 orang berpengetahuan baik $(65,0 \%)$ berpengetahuan cukup sebanyak 1 orang $(5,0 \%)$ berpengetahuan kurang 6 orang $(30 \%)$. Hal ini menunjukkan bahwa sebagian besar Ibu cukup mengerti akan KB Alamiah Metode Amenore Laktasi. Hal ini menjadi salah satu pemahaman umum yang menjadi dasar setiap ibu menyusui untuk mengetahui KB Alamiah Amenore Laktasi. Menurut asumsi penulis hasil penelitian ini menggambarkan pengetahuan ibu tentang MAL baik dan perlu untuk di pertahan kan. Dari hasil penelitian bahwa gambaran pengetahuan ibu menyusui tentang Metode Amenorea Laktasi baik dan perlu juga untuk ditingkatkan karena ibu yang memiliki pengetahuan yang tinggi belum tentu dapat menerapkan kontrasepsi MAL apalagi pada ibu yang berpengetahuan cukup, karena pengetahuan yang baik belum tidak dapat menjamin sikap dan perilaku yang baik pula.

Dari tabel 2 Pendidikan SD diatas sebagian besar berpengetahuan kurang sebanyak 1 orang. Pendidikan SMP berpengetahuan baik sebanyak 1 orang $(5,0 \%)$ berpengetahuan kurang 2 orang (10\%). Pendidikan SMA berpengetahuan baik 10 orang (50\%) cukup 1 orang $(5,0 \%)$ kurang 2 orang $(10,0 \%)$. Perguruan Tinggi berpengetahuan baik sebanyak 2 orang (10\%) berpengetahuan cukup 1 orang $(5,0 \%)$ berpengetahuan kurang orang. Menurut asumsi penulis berpendidikan SMA sebanyak 16 orang (50,0\%) sebagian besar sangat mempengaruhi pengetahuan ibu tentang KB Alamiah Metode Maenore Laktasi dimana semakin tinggi pendidikan seseorang maka ia akan lebih mudah menerima hal hal yang baru dan mudah menyesuaikan dengan hal yang baru pula, selain pensisikan usia juga mempengaruhi pola pikir seseorang dalam menerima informasi dimana sumber informasi yang bayak akan memiliki pengetahuan yang luas salah satu sumber informasi yang berperan penting bagi pengetahuan yaitu media massa. Pengetahuan bisa juga di dapat dari beberaa sumber antara lain : media cetak, elektronik, keluarga, teman dll.

Berdasarkan tabel diatas dari pekerjaaan Petani sebagian besar berpengetahuan baik 11 orang $(55,0 \%)$ berpengetahuan cukup 1 orang berpengetahuan kurang 6 orang. Berdasarkan pekerjaan wiraswasta berpengetahuan baik ada sebanyak 2 orang (5\%). Berdasarkan pekerjaan Swasta berpengetahuan kurang ada sebanyak 1 orang (5\%). Menurut asumsi peneliti seseorang yang bekerja sebagai petani akan lebih memiliki waktu luang untuk mencari atau mendapat informasi tentang KB MAL dari pada ibu dengan pekerjaan lain. Hal ini juga dapat dipengaruhi oleh pendidikan dan pengalaman seseorang, selain pendidikan pekerjaan juga mempengaruhi pengetahuan seseorang dalam menerima informasi dimana sumber informasi yang bayak akan memiliki pengetahuan yang luas salah satu sumber informasi yang berperan penting bagi pengetahuan yaitu media massa. Pengetahuan bisa juga di dapat dari beberapa sumber antara lain : media cetak, elektronik, keluarga, teman dll.

\section{Kesimpulan}

Dari hasil penelitian yang telah dilakukan terhadap Tingkat Pengetahuan Ibu Menyusui Tentang KB Alamiah Metode menore Laktasi Di Klinik Bidan Kristina Tahun 2021 serta pengolahan data yang dilakukan, dapat diambil kesimpulan :

Dari hasil penelitian sebagian besar berpengetahuan Baik sebanyak 13 orang

Dari penelitian ini, sebagian besar berpendidikan SMA sebanyak 10 orang, dikategorikan berpengetahuan baik. 


\section{Health Caring: Jurnal Ilmiah Kesehatan}

Volume: 1 | Nomor 1 | Januari 2022 | E-ISSN: xxxx-Xxxx |

DOI: doi.org/healthcaring.v1n1.1248

\section{Referensi}

Arikunto, S. 2013.Prosedur Penelitian Suatu Pendekatan Praktik. Edisi Revisi. Jakarta: PT. Rineka Cipta

BKKBN. Survei Demografi Dan Kesehatan: Kesehatan Reproduksi Remaja 2018 [Internet]. Badan Kependudukan dan Keluarga Berencana Nasional. Jakarta; 2017. Available from: http://www.dhsprogram.com.

Donsu, J.D.T. (2017). Pisikologi Keperawatan. Yogyakarta: Pustaka Baru Press. (2016). Metodologi

Dyah Pratiwi dan S. Sariyati, "Agama dengan Keikutsertaan Keluarga Berencana n (KB) dan Pemilihan Jenis Alat Kontrasepsi pada Pasangan Usia Subur (PUS) di Desa Argomulyo Sedayu Bantul Yogyakarta," J. Ners dan Kebidanan Indones., vol. 3, no. 1, hal. 1, 2016, doi: 10.21927/jnki.2015.3(1).1-9.

Forcepta, B. Obstetri, F. Kedokteran, dan U. Lampung, "Faktor - Faktor Penggunaan Alat Kontrasepsi Medis Operasi Wanita ( MOW ) pada Pasangan Wanita Usia Subur The Factors that Use of Contraception Woman Medical Operation ( WMO ) on Childbearing Age," Obstet. dan Ginekol., no. Sdki 2007, hal. 11-19, 2017.

Kementrian Kesehatan RI. 2018. Riset Kesehatan Dasar. Jakarta: Kemenkes RI. Diakses pada tanggal 24 Januari 2019 dari http://www.depkes.go.id/resources/download/infoterkini/materi_rakorpop_20 18/Hasi1\%20Riskesdas\%202018.pdf

Kontrasepsi Hormonal dan Produksi Air Susu Ibu di Puskesmas Poasia La Ode Alifariki," vol. 11, hal. 9196, 2020.

Melyani, "Hubungan Pengetahuan dengan Sikap dalam Memilih Metode Amenorea Laktasi Pada Ibu Nifas di UPTD Puskesmas Kecamatan Pontianak Utara Tahun 2017," J. KEBIDANAN Akad. Kebidanan Panca Bhakti Pontianak, vol. 7, no. 1, 2017, [Daring]. Tersedia pada: http://jurnal.akpbpontianak.ac.id/index.php/123akpb/article/view/55.

Mubarak,W.I, 2007, Promosi Kesehatan Sebuah Proses Belajar Mengajar Dalam Pendidikan, Yogyakarta, Graha Ilmu.

Notoatmodjo Soekidjo, (2003). Metodologi Penelitian Kesehatan. Jakarta : Rineka Cipta

Nursalam. (2017). Metodologi Penelitian Ilmu Keperawatan: Pendekatan Praktis. (P. P. Lestari, Ed.) (4th ed.). Jakarta: Salemba Medika.

P. U. Subur, L. Belakang, K. B. Alamiah, A. Kontrasepsi, dan D. Rahim, "Dengan Penggunaan Alat Kontrasepsi Dalam Rahim ( Akdr ) Di Wilayah Kerja Puskesmas Pancur Batu Kabupaten Deli Serdang Tahun 2017 UPT Pelatihan Kesehatan SU,” hal. 267-272, 2017.

R. N. Lausi, A. I. Susanti, P. Sari, dan S. Astuti, "Gambaran Metode Amenorea Laktasi Dan Cara Pemberian Asi Eksklusif Di Desa Cipacing Kecamatan Jatinangor,” J. Sist. Kesehat., vol. 3, no. 1, hal. 32-37, 2017, doi: 10.24198/jsk.v3i1.13959.

R. Septalia dan N. Puspitasari, "Faktor yang Memengaruhi Pemilihan Metode Kontrasepsi," J. Biometrika dan Kependud., vol. 5, no. 2, hal. 91, 2017, doi: 10.20473/jbk.v5i2.2016.91-98.

Rani Latifah Filmira dan Mohammad Zainal Fatah, "Determinan Keinginan Penerapan Program KB 


\section{Health Caring: Jurnal Illmiah Kesehatan}

Volume: 1 | Nomor 1 | Januari 2022 | E-ISSN: xxxx-Xxxx |

DOI: doi.org/healthcaring.v1n1.1248

(Keluarga Berencana) pada Remaja Pria Indonesia di Masa Mendatang," J. Heal. Sci. Prev., vol. 4, no. 2, hal. 58-67, 2020, doi: 10.29080/jhsp.v4i2.384.

S. S. . Sry Handayani, Buku ajar pelayanan keluarga berencana. Sewon, Bantul, Yogyakarta: Pustaka Rihama, 2018.

Thomas, (2016). Barriers to Exclusive Breastfeeding Among Mothers During the First Four Weeks Postpartum. Walden Universuity Follow this and additional works at: http://scholarworks.waldenu.edu/dissertations Part of the Human and Clinical Nutrition Commons, Nursing Commons, and the Obstetrics and Gynecology Commons

Wawan, A. \& Dewi, M. (2011). Teori Pengukuran Pengetahuan Sikap dan Perilaku Manusia. Yogyakarta: Nuha Medika 